\title{
Visuality 2021: Media and Communication
}

\author{
NERIJUS STASIULIS \\ Department of Philosophy and Cultural Studies, Faculty of Creative Industries, Vilnius Gediminas Technical University, 1 Trakų Street, \\ 01132 Vilnius, Lithuania \\ Email: nerijus.stasiulis@vilniustech.It
}

\begin{abstract}
The article provides a synopsis of the issues discussed in the 6th international scientific conference Visuality 2021: Media and Communication. The background for the discussions was the tranformations of ways to communicate, also incrusted with the up-todate reflection on the influence of lockdown under COVID-19. The effects of the novel mediated communication on politics, education and art were discussed from different angles. Some presenters focused on the opening of new oppurtunities, others were worried about the disapperance of reality and authenticity. The possibility of visuality to communicate the most abstract scientific and philosophical ideas was also discussed, and visuality proved to be a merging point of many streams of human being in the world. In addition to most up-to-date challenges, the discussion also encompassed a broad historical perspective, down to the Rennaissance.
\end{abstract}

Keywords: communication, media, reality, virtuality, visuality

\section{INTRODUCTORY REMARKS}

On 22-23 April 2021, Vilnius Gediminas Technical University held an international Visuality conference which takes place every two years. This one was the 6th, and it focused on an array of topics in a broad field of media and communication. It featured presenters from five continents and over twenty countries and covered the topics of visuality in entertainment as well as in visual arts, the ethical and societal issues related to visuality, the role of visuality in architecture and urbanism, the relation of visuality, language and education, the aspect of visuality in media and perception and the philosophy of visuality. The conference was opened by six key note speakers from Europe, the United States of America and China.

\section{KEY NOTE SPEAKERS}

John Howkins (the author of Howkins 2013; Howkins 2010) discussed a broad topic of the links between visuality and creativity. He argued that visuality is the core of conceptual creativity. It is experience rather than understanding that influences behaviour. The origins of creativity are imagined in visual terms and then later images are articulated in order to be shared. Although we often have to transform the images into text in order to communicate them, all texts in their origin are visual.

Nico Carpentier (who has authored, among others, Carpentier 2021; Carpentier et al. 2007) presented the documentary film 'Kiruna - A Brand New World' as an audio-visual 
intervention into the struggles over environment. He started with the entangled notions of the discursive and the material and he was emphatic that the two form a non-hierarchical ontological pair. He sought to demonstrate the pain of the dualistic struggle and the one caused by instrumentalism and concluded by pointing to the need of natureculture (the understanding how nature and culture are entangled). The visual, the showing of the active material agency as the soil itself engages in this discursive-material struggle, plays in this task a crucial role.

A designer, artist and researcher Franz Fischnaller (among a multiplicity of works, Fischnaller 2006; 2018) sought to shape the future of immersive gigapixel exhibits. Using a number of examples, he demosntrated how the gigapixel technique allows one to view paintings really close up and in great detail, in great resolution. You can also transform the two-dimentionally of a painting into three dimensions and get the feeling that you are really inside of the painting and its scenario. He emphasised that story telling is a moving force and is of crucial importance for the communication of painting messages by means of this novel technology.

Algis Mickūnas (Mickūnas, Pilotta 1990; for one of his recent works, see Mickūnas, Kačerauskas 2020) reflected on the differences and overlappings of visuality and vision. He asked what it meant to have an image when we do not have the original as is so often the case with our current world immersed in images. An image points to another image. But an image can also be transparent in another way: by pointing from its current presence to its past presence or future presence. Yet, this transparency can also be used to create a comical vision of eternal but earthly life (the vision of biotopia which leads progress).

Asta Zelenkauskaitè (Herring, Zelenkauskaitè 2009; Zelenkauskaitė, Niezgoda 2017) et al. discussed the notions of local, global and glocal in the context of relativism and mass media innovation. She described the move of the internet space from locative media to the sphere of geo-propaganda and geo-influence. The global aspect of online provides a new context for user participation and audience engagement but this can be manipulated for the purposes of foreign political influence.

Joseph J. Pilotta (Mickūnas et al. 2017; Pilotta 2012; Mickūnas, Pilotta 1990; Pilotta 2001) added his own ideas on how electronic and digital media work. He reflected on media in terms of ecology and communicational organisms: in terms of their organising power and symbiotic character. Such a way of styling media allows us to interpret news, to see that there is something else beyond their perspective. After the French Revolution, media as the distributor of messages was supposed to keep the public sphere open without encroaching on the private sphere. Now one says that media manipulates. But at the same time you can be ready for it. He ended up with open questions of what the truth is and whether there is any media which tells the truth.

\section{ENTERTAINMENT, VISUALITY, EDUCATION}

The conference continued on a comical note as quite a few of presentations focused on humour and fun. Nuno A. Jerónimo, José C. Alexandre and Angele Tamulevičiūte sought to analyse the role of comedy in the interruption of everyday routines during crises related to 'pests' and emphasized that the suspension of normal ways of life at these times is not solely due to health reasons. They equated humour to a 'largely contagious viral formula'. Ron E. Ringer generalised from the need to be able to laugh at the time of crisis to humour as part 
of the human condition. Hence, animation has also become part and parcel of our current condition. Kristina Stankevičiūte, Catarina Moura and, again, Nuno A. Jerónimo, discussing memes, presented them as stemming from the tendency of the recent artistic landscape towards hybrid forms. As such hybrid forms, memes serve to convey dry and sarcastic humour, they are shared anonymously thoughout times and places, translate new understandings and ever broaden their shifting narratives. The workings of memes presuppose a shared ground of references, wheather conscious or unconscious. Thus the authors of the presentation analysed a case of memes intended to convey opinions on the field of fashion and on the issue of what shared cultural experiences it presupposed. Whereas Vaida Nedzinskaitè-Mitkè discussed comics as comparatively cheap means of visual communication which can be used to form opinions. She emphasised its possible role in historical education and its ability to cement national identity via such a popularization of historical knowledge. Viktorija Prilenska also supported the notion of a 'serious game' which combines an engaging gameplay with efficient didactics. The delicacies of measuring the efficiency of such didactics were discussed. While Mitkës approach was directed more towards the youngest of school students, Prilenska's theory was tested on university-aged students. Judita Kasperiūnienè and Donata Bocullo also discussed the education of school children as subtopic in a broader field of communication scientific knowledge to non-experts. According to them, comics are visual-metaphor based narratives which can be used to entertainingly and efficiently convey the complicated knowledge of science, engineering, technology and mathematics. They also portrayed an example of (future) teachers involved with comics creation tools.

While Aiste Ptakauske portrayed an example of students involved in the making of visual entertainment as part of their studies. Her students had produced an award winning web series 'Little Incidents' and she herself had received The Best Creator Award in Seoul Webfest 2019. She explained how she uses the process of producing a web series to help students take responsibility for their learning and work in interdiscilinary teams.

Tomas Mitkus directed his research exclusively to adults: he discussed adult animation as the fastest growing segment in the industry. However, the growth is hindered by self-censorship, also with relation to the mature themes. Thus, Mitkus analysed the reasons for this self-censorship which persists despite the abolition of formal censorship.

\section{EDUCATION AND LANGUAGE}

The changes in communication and education introduced by the 'COVID-19' crisis were also analysed by Živilè Sederevičiūtè-Pačiauskienè, Vaida Asakavičiūtè and Ilona Valantinaitè. They were worried that mediated interaction removes a true dialogic relationship and thus deprives the participants of responsibility. An interactive dialogue constructed through social networks only mimics the illusion of closeness because they are deprived of the authenticity of human face and voice. Without personal dialogue true education is not possible. Virtual dialogue in digital space can be termed a quasi-dialogue focused on creating and maintaining superficial, consumer, business and short-term relationships, which are not based on values and intrinsic connection. Maciej Białous analysed the impact of the crisis on cultural and creative sectors. Attractive use of visual language proved to be a possible means for an effective online communication. He provided a review of the visual language used by cultural institutions on their websites and social media pages. Irena Ignotavičienè and Indrè Darginaitè analysed the influence on the use of the very term 'COVID-19' on the current English language. 
Visual communication via social networks received a great deal of attention. Omar Larouk and Marina Garanovich combined their efforts to analyse educational information services offered by YouTube and Daily Motion. They evaluated the informational services related to the visuality of the contents by concentrating their observations on the essential macro-criteria such as usability services, information search services, personalised access and recommendation services, documentation services and participative services.

Svitlana Pryshchenko's focus was on visual language of colour in advertising communications. She raised the issue of visual noise created by visual ads (large billboards) in the city centers of Eastern European cities as opposed to Western European cities. Current visualization of advertising ideas is a synergy of colour, creativity, and digital technologies. So, creating visual images is a difficult task in terms of targeted psycho-emotional and associative impact on consumers in different cultural regions, taking into account ethno-art traditions. Daiva Milinkevičiùte took us to Vilnius at the beginning of the 19th century to present the successful ways of international academic communication that her Alma Mater, Vilnius University (then Vilnius Imperial University), was engaged in.

Karolina Ferreira Fernandes brought us back to the present to introduce us to the visual culture in modern Catholic Church. The role of visual symbols in the Catholic Church has been growing. The Catholic Church has taken to the social media. Ferreira treated visual symbols as a socio-cultural fact and emphasised the role of observers in the process of creating, receiving and decoding visual messages.

Another case study of social networks was provided by Katarzyna Molek-Kozakowska and Agnieszka Kampka who analysed an Instagram based election campaign. Their ethical motivation was to offer guidance on how to sort images according to how they represent or misrepresent reality to make it fit for the purposes of the elite.

\section{SOCIETY AND ETHICS}

Ulrika Varankaite, in her study of media's (especially, musical) influence on listeners' perceptions, claimed that perception of music including visual imagery is more social than personal since music exists within the same sociocultural context where the music is produced and where the listeners come from. Listening to music is a complex and creative process due to the audible music having the capacity to evoke various responses that include multifaceted extramusical associations full of visual content influenced by the sociocultural environment and, specifically, media.

Wadim Strielkowski and Elena Korneeva analysed the influence of social networks on traditional media. Their presentation explored the perspectives for further digitalization of social media and drew new pathways for their further development. Eric Mark Kramer noticed that it is increasingly difficult to tell reality from fiction in the context of virtual images. It undermines the possibility for justice which is founded on the ability to determine true states of affairs. He sought to lay a foundation to address the issue of the metaphysical and epistemological veracity of images in the eyes of audiences. Joshua Onome Imoniana and Debora Kobayashi also dealt with an akin topic: that of fraud. Their study examined how internal control environment connects to the goal of sustainable development to curb corporate fraud. They concluded that internal controls with the monitoring activities promote the direction towards more responsible and stronger institutions. Zenona Atkočiūnienè and Daiva Siudikienè discussed the management of the interaction of communication for fostering innovation in creative organizations. They sought to determine how communication 
management solutions drive employee creativity in generating knowledge-based continuous innovation in creative organizations. On their way of realising this goal, they revealed the importance of communication management as an essential activity of an organization in creating innovations in the context of dynamic environmental change, analysed the expressions of knowledge management as a potential factor of innovation promotion and revealed the links between communication, knowledge and creativity in the process of innovation creation in creative organizations.

On a political note, Basia Nikiforova explored the emancipative potentiality of visuality. Visual image of the important events allows one to extract sameness even from what is unique. The mass migration and the COVID-19 crisis have returned us to the reality of embodied and embedded world. In the case of migration, Europe has dealt with an 'alien body', in the case of political health care - with 'infected sick body'. The crises of mass migration and COVID-19 have introduced the process of re-territorialisation and thus ended the era of 'electronic landscapes' with its entirely disembodied and disembedded virtual world. Bojan Žalec's political notions dealt with the integral theory of resonance developed by Hartmut Rosa which has aroused tremendous interest in recent years. He used the theory to adress the challenges of ecological challenge and the threats of populist anti-democratic movements to Western liberal democracy as well the very question of meaning. Ewa Wylezek-Targosz complemented to this topic by analysing and commenting on visual artistic representations of the American Flag on which the American identity (also, with its gun culture) is largely based.

\section{URBANISM AND ARCHITECTURE*}

The visual aspects of the intersecting topics of city, culture and creativity (Betlej, Kačerauskas 2021; Kačerauskas 2011; Kačerauskas, Kaklauskas 2014; Kačerauskas 2016, 2017, 2018) were also discussed.

Borbála Jász analysed the symbols of power in the form language of architecture and the tendencies of visual representation in the different versions of Renaissance and Baroque, from the small scale of individual buildings to the large scale of urban design. She presented case studies on symbolising the conceptual usage of visual communication in the spirit of ideological transformation. Gábor Kovács, drawing on Lewis Mumford, saw cities as encoded messages of civilisational values. Human beings living in the city are not only passive possessors of a heritage determining one-sidedly their actions but they do modify and restructure urban spaces: architecture forms our values, at the same time our values influence the concrete arrangement of architecture; as a consequence of this idea, city-planning is vitally important for the direction of a civilisation's future historical way.

Tomas Kačerauskas combined anthropological, visual, borderland and phenomenological studies in order to analyse the representation of Sainthood in Vilnius city. The Saints represent the symbolic walls or religious borders inside a city, inside a state and inside a region. The life of a Saint should be extraordinary, and should provoke changes in the social order or even evoke misunderstandings. The canonization is like a narrow gate, not as much for

* The Conference Section 'Visuality, Urbanism and Architecture' was based on the Hungarian-Lithuanian joint project 'Sustainable Urban Development (SUD) Concepts - Philosophical, Sociological and Historical Analyses'within the framework of a bilateral agreement of the Hungarian and Lithuanian Academies of Sciences. Code: NKM 2019-32 (2020-2022). 
the people as for the nations that have more or less political-religious weight. The public cult of the Saints is inseparable from an identity of a particular city or state.

Béla Mester discussed the way other prominent figures - intellectuals and philosophers - were visually represented in the Hungarian Reform Era (1825-1848) and how it acquired a special role under conditions of the establishment of machinery of the modern cultural industry. In the context of the East-Central European cultural nation building, portraits made in this crucial epoch created a solid visual canon of the national classics; their figures appeared in the school textbooks, on the monuments and in the handbooks. Another visual feature of this cultural transition was the changing structure of the public realms of the cities, because of the functional transformation of the usage of urban places, from the public cafés and private saloons to the fixed places of the political mass meetings. As a historical counter-balance for these star portraits, their caricatures also appeared.

Vilmos Katona sought to rediscover the meaning of house façades - the 'skin' of the city. The façades carry messages and collective memories on different scales, not only allowing us to construe our built environment, but even inducing urban rituals. By building new stages of urbanism, our new experiences may converge into a comprehensive understanding of urban façades and our tectonic culture in general. By deciphering aesthetics as the means of visual communication, we could also achieve long-term models of participatory city rehabilitations, the reuse of public space and social revitalization.

Liudmila Starostova cared about new methods of speaking about the Russian avant-garde in architecture, fine arts and design, taking into account modern communication technologies and the mindset of a modern audience. Her goal was to understand how to make it better known to the bulk of population.

Veronika Urbonaitè-Barkauskienè explored the dramatic change from conservative to explosive unsanctioned visuality of the urban space which began as the graffiti trend on the East Coast of the USA in the 1960's and then disseminated into Europe and worldwide. The presenter discussed how this trend has developed in Vilnius since the 1980's, the anti-graffiti media campaign which it had to face after its golden age and the new tactics in adopted in order to remain visible in Vilnius.

Luís Moreira Pinto and Claudia Beato addressed the troubles that were caused by COVID-19 in the tourism section and how this situation led to a reflection on creativity sustained on specificities and supported by technology and on marketing of cities in order to reflect the real needs of the population, how new technologies can be applied to promote the cities, the streets, but above all, how important a reflective knowledge about the city in which we live, walk and work is.

Zsolt Batori describes how city can be captured using photograpic abstraction. According to Arthur Danto (1981), on whose work Batori's presentation was based, the way an artwork presents its content is part of its artistic meaning. Photographic abstraction is one of the important photographic means of the general artistic modes of presentation Arthur Danto discusses. Batori also used Roland Barthes' (1981) notion of punctum which results from an interplay between the kind of photographic abstraction utilised and the depicted content of the image. Our interest in the photograph only transcends the depicted content when punctum stabs us with the way the depicted content is presented by the image (when our interest in the photograph is based on and extends to our interest in the phenomenon itself that is being depicted in the image). Batori examplified this by displaying his own photography series 'Huerta y ciudad' ('The Orchard and the City'). 


\section{PERCEPTION, MEDIA AND PHILOSOPHY}

A large part of presentations had a philosophical ground. Fabio Bartoli sought to adapt Kierkegaard's insights to the age of virtuality - the analysis of seduction to the case of social networks. Dalia Marija Stančienè analysed social bubbles from the perspective of Peter Sloterdijk's media philosophy in the context of spherical universalization. Dario Martinelli discussed the very notion of screen in audiovisual communication: screens are not just neutral mediators of text but participate actively in the process. Lucy Baxter even demonstrated how virtual reality can be used as a practical healthcare intervention. Whereas Paulo Alexandre e Castro linked the current dominance of visuality to a form of blindness because true visuality is not just visual and it also has olfactory and auditory qualities and has to do with the invisible element of things. Carlos Dias, Bruno Reis and Paula Lopes in their presentation 'The Lies We Do Not See' were also worried about the disapperance of reality in the age of videos behind deep fakes and presented their efforts to identify scientific instruments to detect and prevent this phenomenon of deep fakes.

Alexey Timashkov added to this in his presentation on visuality of emotional information in Fake News. His point of departure was the psychological and physiological studies of the links between emotions and visuality. The visuality in the message contains an information of its own and can even contradict verbal information and can thus be used to convey the important in the message. Marina Garanovich and Omar Larouk addressed the role of socio-perceptual stereotypes in the process of human perception and dedicated their experimental sociopsycholinguistic study to it. Socio-perceptual stereotypes turn out to be very important supporting elements in the process of perception. An original socio- and psycholinguistic experiment with the presentation of a photo of an unfamiliar girl to 80 informants who differed in the factors 'gender', 'age' and 'education' demonstrated that the actualization of a particular type of socio-perceptual stereotype in the verbalised perception of a stranger depends on the speaker's social affiliation. Margarita Gedvilaitė-Kordušienè also analysed stereotypes, i.e. how stereotypes related to childlessness are communicated in comments in the news portals. Because the Internet comment section allows the expression of politically incorrect argumentation and has the potential to reveal a wide spectrum of opinions. She found that hegemonic, polemic and emancipated representations of childlessness manifest in the analysed comments.

Viktorija Žilinskaitè-Vytė also stepped on the boundary between reality and virtuality and described how this boundary was redrawn in the context of COVID-19. Rozália Klára Bakó and Gizela Horváth also explored the connection between virtuality and reality and presented recent cases of real books made on the basis of posts in social networks or internet blogs.

Enrico Ceko addressed the intertwining of visuality and communication in a business related field. Some of the relations he discussed were those of collective intelligence, social networks, co-creation, social technologies, social innovations and creative industries. As per ISO 9001:2015 quality management systems standard, communication plays an important role in understanding clients' needs, desires and satisfaction, as well as understanding the suppliers' role in business, both of them (clients and suppliers) as stakeholders, involving philosophical aspects of communication during this process, impacting collective intelligence, technologies and working environment in all sectors. Migle Eleonora Černikovaite examined the impact of different visual means on digital communication, exploring specifically the impact of visual elements on the effectiveness of newsletters. She found that the user, who evaluates the design 
of the newsletters submitted to him, captures the graphic elements in search of design accents. Illustration helps to create a solid composition whose underlying emphasis is on the connection of the elements used in the design. After eliminating the photos, the interviewee's attention shifts to the text and colour. Visual communication is best suited for the user to accept constructive information and verify that schematic presentation of information is equivalent to visual material when communicating in a virtual environment. Marina Valentukevičienè and Vytis Valatka described the impact and response of visuality, media and education under COVID-19. The presentation style of visual, ready-to-use examples is the best way to create holistic learning approach for the students. The case of 'Eco-Design' subject showed that simple guidance is an important element of visual tools for Master Students working on 'Ecological Masks, Green-house and Ecological Hemp' projects. The general reaction of the students was that the case study of every team-work related to 'Eco-design' from Spain, Ghana and Lithuania was very useful to the real practice under lockdown conditions.

Jüratė Černevičiūtė and Lina Liebutė discussed the cultural probes method which is used to communicate with the target audience about panic attacks. Cultural probes method has brought visuality to the field of research and connects the designers with people and places for which they design. To leave ample room for designers' imaginations and to provoke the participants, the elements of surrealism, literature and situationism are integrated into the aesthetics of cultural probes kit. Adapting these elements helps to create a spontaneous and playful approach to ordinary questions.

A more synoptic view was also offered. Eglè Jaškūnienė provided an overview of how the field of communication research has changed over the last two years. While Arto Mutanen provided an overview of the general problems in the current philosophy of communication. He also devoted a great deal of attention to possible worlds semantics which interprets language as a function from possible worlds to extensions: it, as a flexible method, allows us to analyse meaning of non-literal expressions. Gytis Dovydaitis also touched upon the practice of language by analysing the way concepts are created in action in the internet space. $\mathrm{He}$ employed the concept creation machinery conceptualised by Deleuze and Guattari (1996) in 'What is Philosophy?', and principles of paralogistic thinking proposed by Lyotard, finally arriving at a new conceptualization of the internet space as the meteorological pressure system. Ina Nalivaika and Katsiaryna Zhuk also spoke about the creativity of language, namely, the everyday language. They used the insights of Merleau-Ponty whose remarks on the inauthenticity of everyday language are counterbalanced by his definition of language as a bodily gesture which is a flattering attempt to even it with basic bodily ways to interact with the world (such as perception) which are situated within the domain of everyday life. Nerijus Stasiulis spoke about two sorts of language: based on definition and based on paradigm, and he suggested there is a need to forego their opposition for the sake of authentic communication.

\section{CINEMA AND THEATRE}

Ignas Staškevičius and Audrius Lelkaitis presented the film 'Absolute Truth' whose co-producers they are. It consists of three parts to convey three different perspectives: the first one is concerned with the relationship between people, the second one is about the relationship between a person and his gut bacteria, and the third one concerns the questions of God and death. All themes are difficult to visualise and the authors discussed their solutions with respect to this issue. Liu Yong discussed a much older movie 'Gema Dari Menara' (1968) and he portrayed how the aesthetic values of the film itself, e.g. narrative structure, plot design, 
camerawork, characterisation and character relationship, as well as the resulting artistic effect manifested by these production elements, collectively as a whole serve to implicate the necessity of internal negotiation between the predominant Islamic ideology and the more and more secularised Bruneian civil society at the time. Whereas Ilona Vitkauskaite drew our attention to the current Lithuanian film as a shaper of Neoliberal identity. She agreed with Antonio Gramsci and his concept of hegemony and asserted that popular cinema, although trivial and schematic at first glance, conveys a hegemonic world view, therefore supporting and strengthening the dominant socio-political and economic system. Donata Bocullo also saw film as an identity producing force. She discussed the problematic question of European identity as such. Fragmentation and diversity that characterise European identity are also deeply etched across its cinema(s). She illustrated it by an example of a transnationally co-produced 'Euro-pudding' movie which was seen as lacking identity.

Jonas Miklavčič analysed how film can visualize even the most abstract of ideas, such as time. With Tarkovsky, he understands time as a subjective category that we cannot measure and which is tied to our experience of life. The film image has the ability to literally capture this subjective time. Tarkovsky adapted all his filming techniques to the display and communication of time, abandoning the Sovie theory of editing and putting a single long shot in the primary place, as only this technique is able to show the captured time in a sufficiently authentic way. Nikolina Lazetic pondered on Theo Angelopoulos' 1995 film Ulysses' Gaze. The visual narrative unfolds as a search for the lost reels, the first film ever made in the Balkans, and it symbolically depicts its destiny. Feminine symbolic figures emerge througout the film, of which the most important seems to be that of Eurydice. Lazetic describes the symbolic meaning of Euryrice's gaze in terms of art and psychoanalysis. Viktorija Lankauskaite focussed on Guillermo del Toro's Shape of Water and its Amphibian Man. Creature cinema and monster films offer a powerful tool to address the issues in society as well as in ourselves. While the older films have imagined monsters only as threats and demanded for their destruction as a symbol of overcoming those issues, for a while now, the cinema landscape has been changing, and monster often appears as a character that is only misunderstood and unreasonably outcast, communicating new meanings to us.

Asta Petrikienė, on the other hand, focused on the changes in real life: in the very Lithuanian theatre industry during COVID-19. The theatre did not attract the same number of spectators but online access allowed them to reduce this difference from previous years. The state theatres only partially exploited the online possibilities: stable national funding may have added to that. Of course, moving performance online and depriving them of live audiences is a problem in itself. Ina Pukelyte analysed namely the response of Kaunas National Drama Theatre during COVID-19. She distinguished two phases in the development of virtual communication unfolded: in the spring 2020 and the second one, which started in November 2020. Comparing the two, she concluded that virtual communication can be successful with respect to younger audiences.

\section{CONCLUDING REMARKS}

The presentations combined the most general philosophical reflection on visuality and communication with the most up-to-date expositions of current visual phenomena and their application in a variety spheres of life. Visuality proved to be an all encompassing root of both our very thought and of the appearance of our life in either real or virtual environments. As usual in this context, the ontological question of the dangers to reality loomed large but it 
was combined with enthusiasm for new possibilities opened up by new ways of visualising communication. Perhaps unsurprisingly, a number of presentations were concerned with the context of COVID-19 which proved to be part of the movement towards different ways of communication as well as even the driving factor behind them.

\section{References}

1. Bailey, O.; Cammaerts, B.; Carpentier, N. 2007. Understanding Alternative Media. Milton Keynes: Open University Press.

2. Betlej, A.; Kačerauskas, T. 2021. 'Urban Creative Sustainability: The Case of Lublin', Sustainability 13: 4072 .

3. Carpentier, N. 2021. Iconoclastic Controversies: A Photographic Inquiry Into Antagonistic Nationalism. Bristol: Intellect. In press.

4. Deleuze, G.; Guatarri, F. 1996. What is Philosophy? Columbia University Press.

5. Fischnaller, F. 2006. E-Art. Arte, Società e Democrazia Nell'era Della Rete. Editori Riuniti.

6. Fischnaller, F. 2018.'The Last Supper Interactive Project. The Illusion of Reality: Perspective and Perception', in Putting Tradition into Practice: Heritage, Place and Design. INTBAU 2017. Lecture Notes in Civil Engineering, Vol. 3, ed. G Amoruso. Cham: Springer.

7. Herring, S. C.; Zelenkauskaitè, A. 2009. 'Symbolic Capital in a Virtual Heterosexual Market: Abbreviation and Insertion in Italian iTV SMS', Written Communication 26(1): 5-31.

8. Howkins, J. 2010. Creative Ecologies: Where Thinking is a Proper Job. Transaction Publishers.

9. Howkins, J. 2013. The Creative Economy: How People Make Money from Ideas. UK: Penguin.

10. Kačerauskas, T. 2011. „Miesto erdvès ir kultūros naratyvai“, Urbanistika ir architektūra 35(2): 141-146.

11. Kačerauskas, T.; Kaklauskas, A. 2014. „Kūrybinis miestas: mitai ir utopijos“, Filosofija. Sociologija 25(3): 190-199.

12. Kačerauskas, T. 2016. 'Environmental Discourses and the Question of Creative Environment in a City', Journal of Environmental Engineering and Lanscape Management 24(2): 108-115.

13. Kačerauskas, T. 2017. 'Philosophical Aspects of Urban Strangeness: The Case of Vilnius', Studies in East European Thought 69(2): 143-152.

14. Kačerauskas, T. 2018. 'Urban (Un)sustainability: Cases of Vilnius's Informal and Illegal Settings', Sustainability 10(12): 4615.

15. Kačerauskas, T.; Mickūnas, A. 2020. In Between Communication Theories Through One Hundred Questions. Cham: Springer.

16. Mickunas, A.; Murphy, J. W.; Pilotta, J. J. 2017. The Lived World of Social Theory and Methods. Nova Science Publishers.

17. Pilotta, J. J.; Mickūnas, A. 1990. Science of Communication: Its Phenomenological Foundation (Routledge Communication Series). Routledge.

18. Pilotta, J. J. 2001. Communication and Social Action Research (Hampton Press Communication Series: Communication and Social Organization). Hampton Press.

19. Pilotta, J. J. 2012. Communication Despite Postmodernism. Nova Science Publishers.

20. Zelenkauskaite, A.; Niezgoda, B. 2017. “Stop Kremlin Trolls": Ideological Trolling as Calling Out, Rebuttal, and Reactions on Online News Portal Commenting', First Monday 22(5). 
NERIJUS STASIULIS

\title{
Vizualumas 2021: medijos ir komunikacija
}

\begin{abstract}
Santrauka
Straipsnyje pateikiamas šeštojoje tarptautinèje konferencijoje „Vizualumas 2021: medijos ir komunikacija" aptartų problemų sinoptinis vaizdas. Problemos buvo gvildenamos komunikacijos būdų transformacijos fone, $\mathfrak{i}$ kurị įsiterpe ir šio meto realijas atspindintis COVID-19 pandemijos įtakos apmąstymas. Itvairiais aspektais aptarti naujos medijuotos komunikacijos padariniai politikai, švietimui ir menui. Kai kurie pranešejai susitelkè ties naujų galimybių atverimu, kiti išsakè susirūpinimą dèl nykstančios realybès ir autentiškumo. Aptartos galimybès vizualiai komunikuoti abstrakčias mokslines ir filosofines idejjas. Paaiškèjo, kad vizualumas yra daugybės žmogaus buvimo pasaulyje srovių susiliejimo taškas. Greta naujausių iššǔkių diskusijoje atsispindejjo ir plati istorinė perspektyva, siekianti renesansą.
\end{abstract}

Raktažodžiai: komunikacija, medijos, realybè, virtualybè, vizualumas 